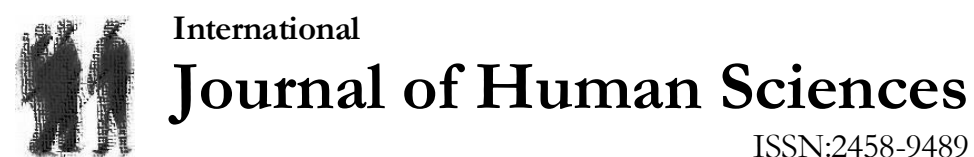

Volume 15 Issue 4 Year: 2018

\section{Forest fire risk analysis via integration of GIS, RS and AHP: The Case of Çanakkale, Turkey}

\author{
Cengiz Akbulak ${ }^{1}$ \\ Hasan Tatli ${ }^{2}$ \\ Gürcü Aygün ${ }^{3}$ \\ Bülent Sağlam ${ }^{4}$
}

\begin{abstract}
Forest fire is one of the high-risk natural disasters in the north-western Anatolia section of Turkey. This paper suggests a new approach based on Geographic Information Systems (GIS), Remote Sensing (RS) and Analytical Hierarchy Process (AHP) for the development of forest firerisk model. The proposed approach includes human factors as well as environmental factors. In this context, the 12 variables defined under anthropogenic and physical factors in the proposed model are the slope, elevation, aspect, vegetation type, crown closure, Normalized Difference Vegetation Index (NDVI), distance to road, settlement, and agricultural areas, population density, previous fires, and Canadian Forest Fire Weather Index (FWI). For each variable, a layer was created in the GIS database environment. GIS-layers were classified, considering the risk of potentially generating forest-fire of the relevant variables. In addition, to generate risk maps, the weights used in these GIS-layers were obtained by applying the AHP technique. One of the major results of the study shows that the rates of "extreme", "very high", "high", and "moderate" risk areas are $3.87 \%, 63.46 \%, 32.13 \%$ and $0.53 \%$, respectively. Another important result is that there are not observed the so called "no risk" and "low risk" classes in the region. The results let us to make a conclusion that the natural and human factors having significant contributions the region to be fire-prone. Yet, these results also indicate that rather than emphasizing forest-fire preparedness and mitigation, policy-makers manage forest-fires through reactive, crisis-oriented approaches. In contrast to crisis-based management plans, this study suggests that risk-based preventive plans should be developed and implemented.
\end{abstract}

Keywords: Forest Fire; Risk Analysis; GIS; AHP; Remote Sensing; Turkey.

\footnotetext{
${ }^{1}$ Prof. Dr., Department of Geography, Çanakkale Onsekiz Mart University, cakbulak@,comu.edu.tr

2 Prof. Dr., Department of Geography, Çanakkale Onsekiz Mart University, tatli@,comu.edu.tr

${ }^{3}$ Ph.D. Student, Department of Geography, Çanakkale Onsekiz Mart University, gurcuaygun@hotmail.com

${ }^{4}$ Prof. Dr., Faculty of Forestry, Artvin Coruh University, bsaglam@artvin.edu.tr
} 
Akbulak, C., Tatli, H., Aygün, G., \& Sağlam, B. (2018). Forest fire risk analysis via integration of GIS, RS and AHP: The Case of Çanakkale, Turkey, Turkey, Journal of Human Sciences, 15(4), 2127-2143. doi:10.14687/jhs.v15i4.5491

\section{Introduction}

Forest fires are among the most critical large-scale natural disasters increasing the intensity of suppressions on forests, which are one of the richest biodiversity areas in the natural environment (Carvalho et al., 2011). Despite the advanced technology and the widespread use of this technology to prevent forest fires, as an ecological problem remains to threat the forests. Forest fires annually affect thousands of hectares of areas and cause dramatic changes in forest ecosystems (Goldammer \& Mutch, 2001).

One of the most common problems of all the countries in the Mediterranean Climate Zone, e.g. Portugal, Greece, Spain, Italy, France and Turkey is forest fires. Those fires in the Mediterranean Zone cause damages from 450 to 500 thousand hectares in an average of forests every year (Versini et al., 2013; Turco et al., 2014; Tonini et al., 2017). A great majority of the forests of Turkey in the Mediterranean Basin are also at risk of fire. Even though the occurrence of forest fires in Turkey exhibits a fluctuating trend, an increase in the amount of affected areas and the number of forest fires across the world over the last years in particular has been observed. This case is associated with both population growth and ever-increasing number of fire-causing factors (Ertuğrul, 2005). In Turkey, 12.76 million of 22.3 hectares of forest consists of Level 1 and 2 fire-prone areas. According to the last-10-year fire statistics, an annual average of 8903 hectares of forest has been damaged by 2330 different forest fires on average (GDF, 2017).

Forest fires in Turkey are commonly observed in the coastlines of the Aegean, Mediterranean, and Marmara Regions. Muğla, Antalya, İzmir, and Çanakkale province of this study are the most fireprone regions (SPO, 2001; Altan and Türkeş, 2011; Türkeş and Altan, 2012a,b). As the features of the Mediterranean climate, the fires in the Aegean and Mediterranean Regions in dry and hot summers cause drastic damages to forests. Forest areas between 0 and $400 \mathrm{~m}$ in elevation in the Mediterranean and Aegean Regions are generally listed among Level-1 fire-prone areas (GDF, 2017). Forest fires occurring in fire-prone regions affect vast forest areas and lead to serious financial damages and even losses of lives - if effective pre-fire planning has not been produced on time and the first response has not been successfully provided.

Although forest fires cannot be prevented, identification of the areas with high fire potential by risk analysis offers facilitating opportunities for administrators and end-users (Karabulut et al., 2013). Pre-determination of the areas at high risk can make notable contributions to decision-making processes intended for properly conducted pre-fire plans and intensification fire-preventive measures in these areas. Therefore, a meticulous identification of fire risk levels and the conduction of studies to map them are of great importance to prevent fires.

In recent studies, several fire-risk models have been produced with the effective use of Geographic Information Systems (GIS). For example, Jaiswal et al. (2002) created mapped forest fire risk zones of Gorna Basin in India with the aid of satellite imaging and GIS. They have found that their suggested model based on GIS for the study area was in strong agreement with actual fire-affected sites. Yin et al. (2004), by using GIS, produced forest fire risk zones on Da Hinggan Mountain, one of the most mountainous areas in China. The authors affirmed that the forest fire risk maps produced by their suggested approach are highly reliability. Forest fire risk maps were produced by Chandra (2005) in Uttaranchal of India by GIS and remote sensing (RS). This study shows that using the RS and GIS technology might be very effective in identifying different fire risk zones based on appropriate parameters such as fuel load, slope, aspect, altitude, drainage, distance from roads and settlements. Erten et al. (2005) stated that the data from the Satellite is a suitable instrument for classifying forest places when integrating the parameter topography, vegetation type, vicinity to roads and settlements, the integration of the satellite data into GIS being very useful to determine risky places due to the forest fires in the Gallipoli Peninsula in Turkey. Pradhan et al. (2007) investigated forest fire sensitivity in the vicinity of Kuala Lumpur, Malesia, by employing RS 
Akbulak, C., Tatli, H., Aygün, G., \& Sağlam, B. (2018). Forest fire risk analysis via integration of GIS, RS and AHP: The Case of Çanakkale, Turkey, Turkey, Journal of Human Sciences, 15(4), 2127-2143. doi:10.14687/jhs.v15i4.5491

and GIS technology. They concluded that forest fire susceptibility mapping by RS and GIS technology is very importance for haze detection and fire prevention in the forest areas. Sağlam et al. (2008) identified forest fire risk zones and fire-prone areas in the study carried out in Korudağ Forest in Turkey. A major result of their study shows that using the Landsat imagery provided is a valuable characterization and mapping of vegetation structure and classification with a high accuracy. Assaker et al. (2012) have applied the forest fire risk analysis of Nahr Ibrahim Basin, Lebanon by using RS and GIS. The authors have a conclusion that using the satellite images made possible the coverage of a large surface and consequently facilitated field work. Sringeswara et al. (2012) produced a forest fire risk map and a forest fire management plan for the Kudremukh National Park, India. They revealed that the areas with high frequent fire occurring could not be located with the existing fire-watch towers. Güngöroğlu (2017) determined fire risk in the forest lands in Antalya, Turkey by using GIS and AHP. He underlined that the degree of different risk management might be taken into consideration in the establishment of fuzzy sets approach.

The present study is intended to present a new sophisticate forest fire risk analysis for Çanakkale province, listed among the most fire-prone areas and as one of the sites of frequent forest fire occurs in Turkey.

\section{Material and Methods}

\subsection{Study Area}

Çanakkale is among the forest-rich provinces of Turkey and incorporates two national parks, i.e. Kazdağ1 National Park and Troia Historical National Park. The province is located in the Southern Marmara Region in the northwest of the Anatolian Peninsula (Figure 1). The province, located on Biga and Gelibolu Peninsula, covers an area of $9,887 \mathrm{~km}^{2}$.

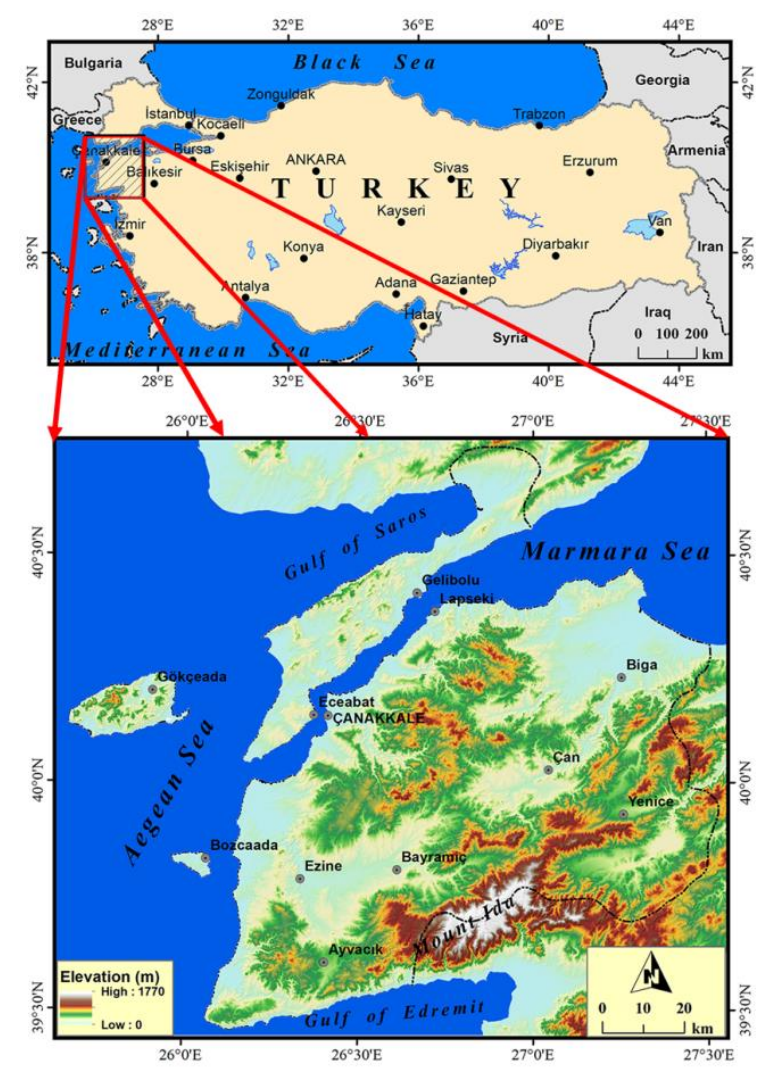

Figure 1. Location Map of the Study Area 
Akbulak, C., Tatli, H., Aygün, G., \& Sağlam, B. (2018). Forest fire risk analysis via integration of GIS, RS and AHP: The Case of Çanakkale, Turkey, Turkey, Journal of Human Sciences, 15(4), 2127-2143. doi:10.14687/jhs.v15i4.5491

It is found in the Subtropical Mediterranean Climate Zone and thus it is hot and dry in summers. In Çanakkale, the annual average temperature is about $15{ }^{\circ} \mathrm{C}$, the hottest month is July $\left(25^{\circ} \mathrm{C}\right.$ on average) and the coldest is February $\left(6{ }^{\circ} \mathrm{C}\right.$ on average). Annual average amount of precipitation is nearly $600 \mathrm{~mm}$. While the area receives a substantial amount of precipitation during winter, the minimum amount is observed in summer. The highest and lowest amounts of mean monthly precipitation are observed in December $(103 \mathrm{~mm})$ and August $(4 \mathrm{~mm})$, respectively. The province, located in the Mediterranean Climate Zone, typically has a sub-humid climate, but a dry one in summer. Dry conditions and drying prevalent northerly winds create the favorable conditions for the breakout and spread of forest fires.

One of the most important nature assets of Çanakkale, $55 \%$ of which is covered by forests is Kaz Mountains (also known as Mount Ida). The northern and western portion of the Kaz Mountains, proclaimed a national park in 1994, is located in Çanakkale province. A vast portion of ecologically rich Kaz Mountains is covered by forests. The forests from the lower to the higher elevations contain black pines, firs, beeches, and its endemic fir trees (Güngördü, 1999). In the Biga Mountains are among the most important forest areas of the province. In the Biga Mountains, one can observe Calabrian pine, Turkish oak, and black pine forests from lower to higher elevations. On the Gallipoli Peninsula, chestnuts and black pines are observed at lower elevations, while Calabrian pines prevail in and around the central zone. The peninsula's sections having been damaged by forest fires are covered by maquis shrubs. Besides the forest, plants in the areas with dunes and high salinity considerably contribute to Çanakkale's vegetation.

\subsection{Datasets}

To produce the GIS database, standard topographic maps at the scale of 1:25,000 were used as basemaps. The digital topographic maps were used to produce slope, elevation, and aspect layers, digital forest stand maps for the production of vegetation type and crown closure data, Landsat (L8 OLI/TIRS) satellite images for NDVI layers (USGS, 2017), and CORINE data for the identification of agricultural areas. Meteorological data and settlement-based population data were used for the calculation of the Canadian Forest Fire Weather Index (FWI) and the production of population density, respectively. Table 1 shows an overview of all data used in the analysis.

Table 1. The Data Used in the Study

\begin{tabular}{|l|l|}
\hline Data description & Source \\
\hline $1 / 25,000$ scale standard topographical maps & General Command of Mapping \\
\hline $1 / 25,000$ scale digital elevation maps & General Command of Mapping \\
\hline Meteorological data & Turkish Meteorological Service \\
\hline Landsat (L8 OLI/TIRS) Satellite images (18/11/2016) & USGS \\
\hline Digital Forest Stand Map (2016) & Çanakkale Regional Directorate of Forestry \\
\hline CORINE land cover data, Level III, (2012) & Ministry of Agriculture and Forestry \\
\hline Population of settlement (2016) & $\begin{array}{l}\text { Turkish Statistical Institute (TurkStat), Address Based } \\
\text { Population Registration System. }\end{array}$ \\
\hline Previous forest fire data (2007-2016) & Çanakkale Regional Directorate of Forestry \\
\hline
\end{tabular}

Variables being considered in forest fire risk analysis vary according to the size of the area where risk analysis is conducted and to the purpose of the study. For the purpose of the present study, the topographic variables "elevation", "slope", and "aspect" were chosen as sub-variables. Meteorological values were included in the analysis as a single parameter through the calculation of FWI. Primary vegetation variables include vegetation type, crown closure, and NDVI, while human variables consist of population density, distance to settlement, road, and agricultural land. 
Akbulak, C., Tatli, H., Aygün, G., \& Sağlam, B. (2018). Forest fire risk analysis via integration of GIS, RS and AHP: The Case of Çanakkale, Turkey, Turkey, Journal of Human Sciences, 15(4), 2127-2143. doi:10.14687/jhs.v15i4.5491

Topographic conditions are among the most influential physical factors in the emergence of forest fires and fire behaviors. Slope, aspect, and elevation are considered as the main topographic factors in several studies (Chandra, 2005; Dong et al., 2005; Pradhan et al., 2007; Adab et al., 2013; Özşahin, 2014; Thakur et al., 2014).

Meteorological parameters were too considered in forest fire risk analyses. Such meteorological variables as temperature, precipitation, evaporation, wind, and relative humidity are decisive in behavior, spread, and speed of fire (Ghobadi et al., 2012; Türkeş and Altan, 2012a,b; Tatli and Türkeş, 2014). Accordingly, the FWI values included in the analysis to account the meteorological effects on the fire risk (Carvalho et al., 2008; Camia et al., 2008; Dimitrakopoulos et al., 2011).

Vegetation is one of the most important factors starting forest fires and affecting their behaviors. For the purpose of the study, such vegetation-related variables as vegetation type, crown closure, and NDVI were taken into account. Since vegetation type determines fuel, it is critical for forest fires and one of the most decisive factors considered in fire risk research (Jaiswal, 2002; Chandra, 2005; Sağlam et al., 2008). Additionally, the remote sensing technique was employed to produce NDVI layer, which varies depending on water and nutrients, plant diseases, and other stress factors (Gouveia et al., 2017).

Human activities pose greater risks of forest fires resulting from negligence and accidents (Jaiswal et al., 2002, Vilar et al., 2010). Thus, areas with the denser population and more complicated route networks are more prone to forest fires. Besides, forest areas in the vicinity of agricultural fields are at risk of fire too. The distance to roads and settlements listed as human factors also is tackled in a great number of studies (Jaiswall et al., 2002; Sowmya et al., 2010; Soto, 2012; Thakur et al., 2014; Biasi et al., 2015). Furthermore, it can be asserted that population density is a crucial factor influential in the breakouts of forest fires. Hence, population density together with distance to roads, distance to settlements, and distance to agricultural lands was included in the present research.

The frequency of fires in a certain area is significant to hint that it might be at greater risk of fire. Starting points of the previous fires in a research area suggest that the area is potentially at risk. Therefore, the starting points of fires occurred in the research area over the last decade (2007-2016) were included in the analysis.

\subsection{Methods}

\subsubsection{Forest Fire Weather Index}

Forest Fire Weather Index or fire danger index is a method merging fuel-related and meteorological facts and putting them in a simple numerical order and successfully employed across the world. Meteorological forest fire index system reveals fire danger in rates relying on daily meteorological measurements in relation to a fuel type (Bilgili et al., 2001; Tatli et al., 2017a; Çekmek, 2018). The primary reason for the use of this index is to express fire risk as a complicated concept in a simple number. The most common indices are Canadian FWI system (Van Wagner, 1987) and US National Fire Danger Rating System (Deeming et al., 1978). Besides, Keetch-Byram Drought Index (Keetch and Byram, 1968) and Haines Forest Fire Weather Index (Haines, 1988; Potter et al., 2008; Tatli and Türkeş, 2014) are quite commonly used indices created to control forest fires.

Canadian FWI was used in this study because of it is widely used in the Mediterranean countries and be claimed to yield accurate results (Turner and Lawson, 1978; Vieges et al., 1999; Carvalho et al., 2008; Camia et al., 2008; Dimitrakopoulos et al., 2011). This index is calculated in consideration of such meteorological variables of temperature, relative humidity, wind speed, and precipitation. The calculations were carried out by written a source code based on FORTRAN 2003. The obtained FWI values were transferred into GIS-based medium to produce the FWI layer. 
Akbulak, C., Tatli, H., Aygün, G., \& Sağlam, B. (2018). Forest fire risk analysis via integration of GIS, RS and AHP: The Case of Çanakkale, Turkey, Turkey, Journal of Human Sciences, 15(4), 2127-2143. doi:10.14687/jhs.v15i4.5491

\subsubsection{NDVI}

NDVI is a simple and most commonly used approach in the related studies, such as in Bonneau et al., (1999) and Doğan et al., (2009). This index is very frequently availed of in forestry practices and particularly in forest fire risk estimations. Low NDVI value, considered indicative of vegetation flow in a specific area, is associated with higher fire risk (Gabban et al., 2006; Tatli et al, 2017b). This index is retrieved by the use of reflection values of visible and near-infrared rays (Myneni, 1997; Huete et al., 1999). It is calculated with the following formula on the basis of each pixel (Lillesand \& Kiefer, 1987).

$$
N D V I=(I R-R) /(I R+R)
$$

where IR is the near-infrared band value of the pixel and $\mathrm{R}$ is the red band value. NDVI value ranges between -1 and +1 according to surface cover properties (vegetation, water, soil, etc.). The value closer to 1 refers to lush vegetation, 0 to barren lands or sparse vegetation, and negative value to non-vegetation (Ghobadi et al., 2012). The NDVI values of the research area were obtained by processing Landsat (L8 OLI/TIRS) Satellite Images of 18 November 2016.

\subsubsection{GIS Layers}

GIS is a tool whereby spatial data are digitized, stored, manipulated, managed, analyzed to generate information (Marble et al., 1984; Clark, 1997; Esri 1999; Longley et al., 2001). GIS methodology plays an active role in spatial decision-making thanks to these properties (Tang et al., 2009). This technique has lately come to be used increasingly in forest fire research, offers significant advantages in obtaining effective and applicable results (Sharma et al., 2009; Zheng et al., 2011). GIS allows for inexpensive, fast and high-accuracy analyses in practices such as estimation, modeling, monitoring of fire emergence, organization of extinguishing efforts, determination of post-fire damage (Erten et al., 2004, 2005). Thanks to the advantages it offers, GIS has been effectively used for the purpose of this study. In this respect, layers of the variables employed in the present study were produced in GIS and then fire risk was determined by overlaying these layers in GIS environment.

The elevation, slope, and aspect layers of the analysis were obtained based on digital elevation model (DEM) data by using the digitized contour lines. The raster-formatted vegetation type and crown closure layers were generated with the digital stand maps in vector format. The settlements and highways in the research area were digitized by using the topographic maps of 1:25,000-scale. The distribution of agricultural areas was determined using CORINE (Level III) land cover data and digital stand maps. The starting points of the forest fires having broken out in Çanakkale in the past decade were transferred into GIS environment to produce the layers of previous fires. The buffer analysis was applied considering the distance to settlements, roads, agricultural land and previous fire spots via GIS. The population density, another variable of the study, was calculated based on the administrative borderlines (areas) of the research area and the population size in 2016, and then the results were transferred into GIS. Consequently, each of the variables herein was converted into raster data with a spatial resolution of $100 \mathrm{~m}$.

\subsubsection{Risk Score of the Variables}

The variables of the fire risk analysis were classified in consideration of fire risk and a score ranging between 1 and 10 (Table 2) was assigned to each class. The variables' classes and the scores thereof were determined based on the related literature (Jaiswall et al., 2002; Sağlam et al., 2008; Ghobadi et al., 2012; Malik et al., 2013) and in view of the conditions of the research area. 
Akbulak, C., Tatli, H., Aygün, G., \& Sağlam, B. (2018). Forest fire risk analysis via integration of GIS, RS and AHP: The Case of Çanakkale, Turkey, Turkey, Journal of Human Sciences, 15(4), 2127-2143. doi:10.14687/jhs.v15i4.5491

Table 2. Classes and Ratings Assigned to Variables for Fire Risk

\begin{tabular}{|c|c|c|c|c|c|}
\hline Variable & Classes & Rating & Variable & Classes & Rating \\
\hline Elevation (m) & $\begin{array}{l}0-200 \\
201-400 \\
401-600 \\
601-800 \\
801-1000 \\
1001-1200 \\
1201-1400 \\
1401-1600 \\
1600+\end{array}$ & $\begin{array}{l}10 \\
9 \\
8 \\
7 \\
6 \\
4 \\
3 \\
2 \\
1\end{array}$ & $\begin{array}{l}\text { Distance to } \\
\text { settlement (m) }\end{array}$ & $\begin{array}{l}0-1000 \\
1001-2000 \\
2001-3000 \\
3001-4000 \\
4001-5000 \\
5000+\end{array}$ & $\begin{array}{l}10 \\
9 \\
8 \\
6 \\
3 \\
1\end{array}$ \\
\hline Slope $(\%)$ & $\begin{array}{l}0-5 \\
6-10 \\
11-15 \\
16-20 \\
21-25 \\
26-30 \\
31-35 \\
35+\end{array}$ & $\begin{array}{c}1 \\
2 \\
4 \\
5 \\
6 \\
7 \\
8 \\
10\end{array}$ & $\begin{array}{l}\text { Population density } \\
\text { (people per } \mathrm{km}^{2} \text { ) }\end{array}$ & $\begin{array}{l}0-10 \\
11-20 \\
21-50 \\
51-100 \\
101-500 \\
501-1000 \\
1001+\end{array}$ & $\begin{array}{c}1 \\
2 \\
4 \\
6 \\
8 \\
9 \\
10\end{array}$ \\
\hline Aspect & $\begin{array}{l}\text { Flat } \\
\text { N } \\
\text { NE } \\
\text { E } \\
\text { NW } \\
\text { W } \\
\text { SE } \\
\text { S } \\
\text { SW }\end{array}$ & $\begin{array}{c}5 \\
1 \\
2 \\
5 \\
2 \\
5 \\
7 \\
10 \\
8\end{array}$ & $\begin{array}{lr}\text { Distance } & \text { to } \\
\text { agricultural } & \text { land } \\
(\mathrm{m}) & \end{array}$ & $\begin{array}{l}0-100 \\
101-200 \\
201-300 \\
301-400 \\
401-500 \\
500+\end{array}$ & $\begin{array}{l}10 \\
9 \\
7 \\
5 \\
3 \\
1\end{array}$ \\
\hline \multirow[t]{2}{*}{$\begin{array}{l}\text { Vegetation } \\
\text { type }\end{array}$} & $\begin{array}{l}\text { Calabrian pine, scrub } \\
\text { Black pine } \\
\text { Stone pine, Cyprus oak and } \\
\text { kermes oak }\end{array}$ & $\begin{array}{l}10 \\
9 \\
8\end{array}$ & NDVI & $\begin{array}{l}\leq 0.05 \\
0.06-0.1 \\
0.11-0.20 \\
0.21-0.3 \\
0.3>\end{array}$ & $\begin{array}{c}10 \\
6 \\
4 \\
3 \\
1\end{array}$ \\
\hline & $\begin{array}{l}\text { Juniper } \\
\text { Cedar, hornbeam } \\
\text { Beech } \\
\text { Walnut, fir, cypress, abies, } \\
\text { plane, chestnut }\end{array}$ & $\begin{array}{l}6 \\
3 \\
2 \\
1\end{array}$ & FWI & $\begin{array}{l}0-0.47 \\
0.48-2.91 \\
2.92-5.96 \\
5.97-13.25\end{array}$ & $\begin{array}{c}3 \\
6 \\
8 \\
10\end{array}$ \\
\hline $\begin{array}{l}\text { Stand crown } \\
\text { closure }(\%)\end{array}$ & $\begin{array}{l}\text { Bareland } \\
<11 \\
11-40 \\
41-70 \\
71>\end{array}$ & $\begin{array}{c}1 \\
2 \\
4 \\
7 \\
10\end{array}$ & $\begin{array}{l}\text { Distance to } \\
\text { previous forest } \\
\text { fires spot }(\mathrm{m})\end{array}$ & $\begin{array}{l}0-200 \\
201-400 \\
401-600 \\
601-800 \\
801-1000 \\
1000+\end{array}$ & $\begin{array}{c}10 \\
8 \\
6 \\
4 \\
2 \\
1 \\
\end{array}$ \\
\hline
\end{tabular}

Lastly, a re-classification was conducted with the aid of "reclassify" tool in the Arc-GIS 10.0 software with respect to Table 2 in order to produce raster-formatted layers for each of the variables (Figure 2, 3 and 4). 
Akbulak, C., Tatli, H., Aygün, G., \& Sağlam, B. (2018). Forest fire risk analysis via integration of GIS, RS and AHP: The Case of Çanakkale, Turkey, Turkey, Journal of Human Sciences, 15(4), 2127-2143. doi:10.14687/jhs.v15i4.5491
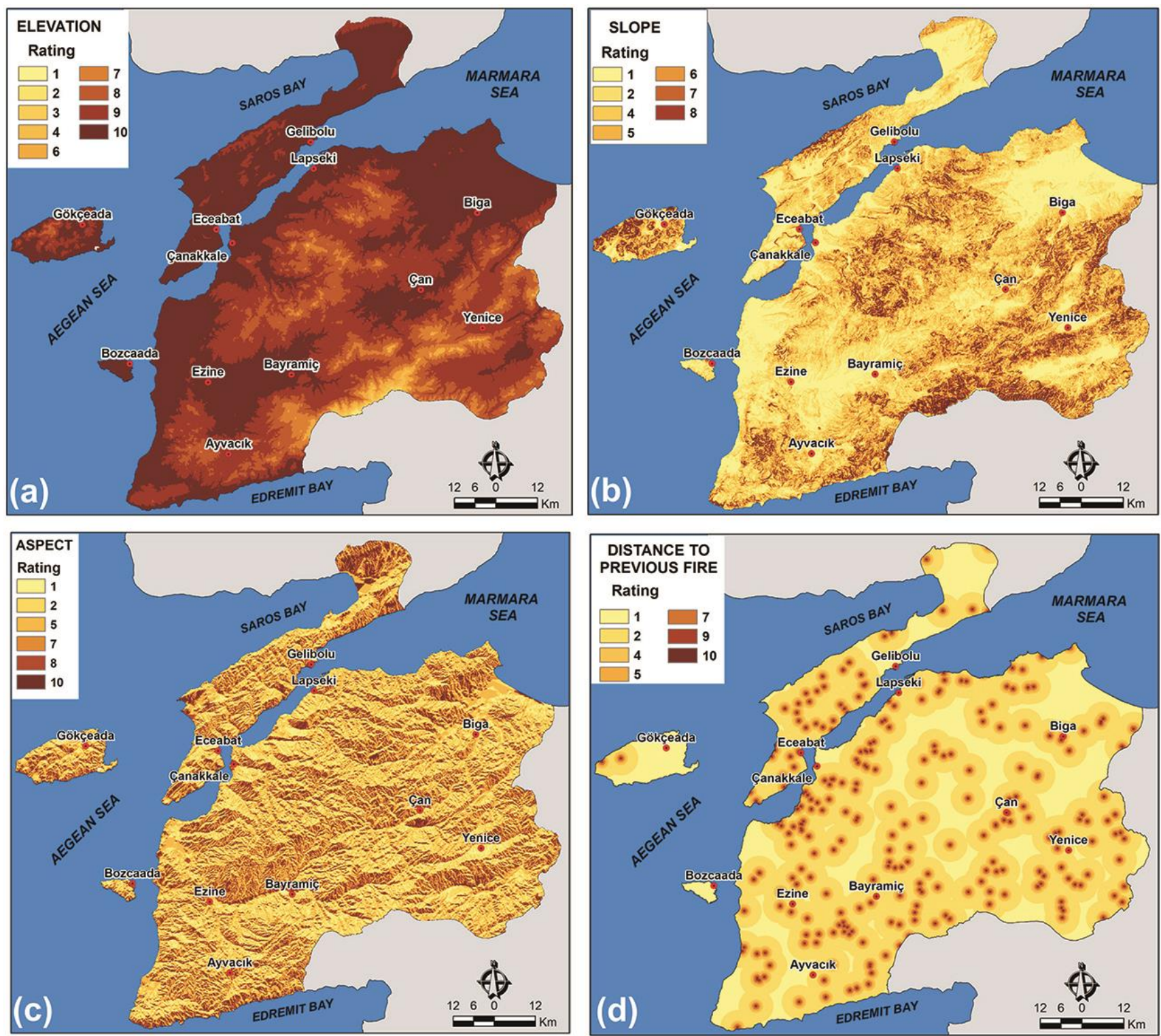

Figure 2. Risk Ratings Assigned to the Factors of Topographic and Previous-Fires: Elevation (a), Slope (b), Aspect (c), and Distance to Previous Fire (d). 
Akbulak, C., Tatli, H., Aygün, G., \& Sağlam, B. (2018). Forest fire risk analysis via integration of GIS, RS and AHP: The Case of Çanakkale, Turkey, Turkey, Journal of Human Sciences, 15(4), 2127-2143. doi:10.14687/jhs.v15i4.5491
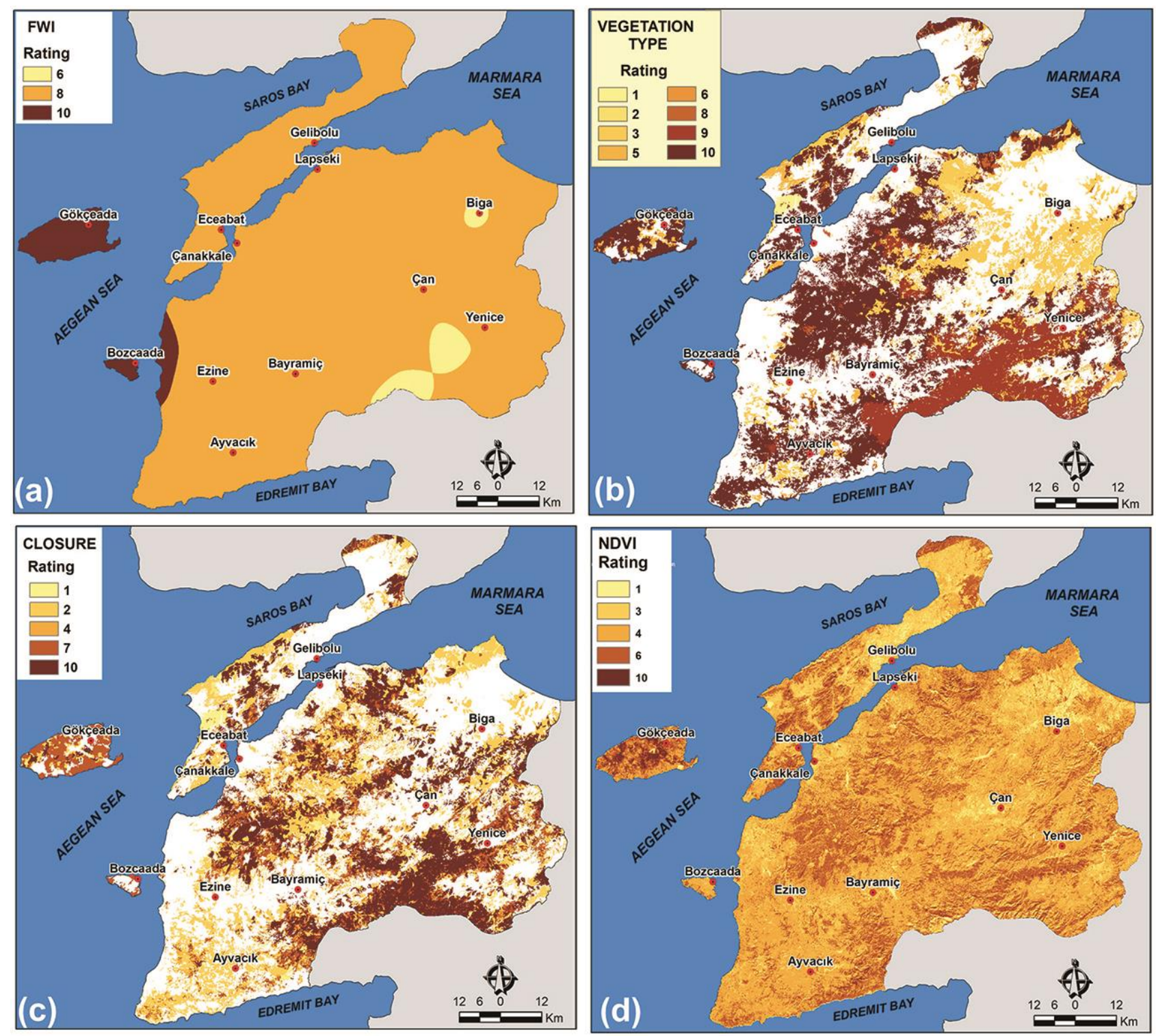

Figure 3. Ratings Assigned to FWI and Vegetation Variables for Forest Fire Risk: FWI (a), Vegetation Type (b), Closure (c), and NDVI (d). 
Akbulak, C., Tatli, H., Aygün, G., \& Sağlam, B. (2018). Forest fire risk analysis via integration of GIS, RS and AHP: The Case of Çanakkale, Turkey, Turkey, Journal of Human Sciences, 15(4), 2127-2143. doi:10.14687/jhs.v15i4.5491
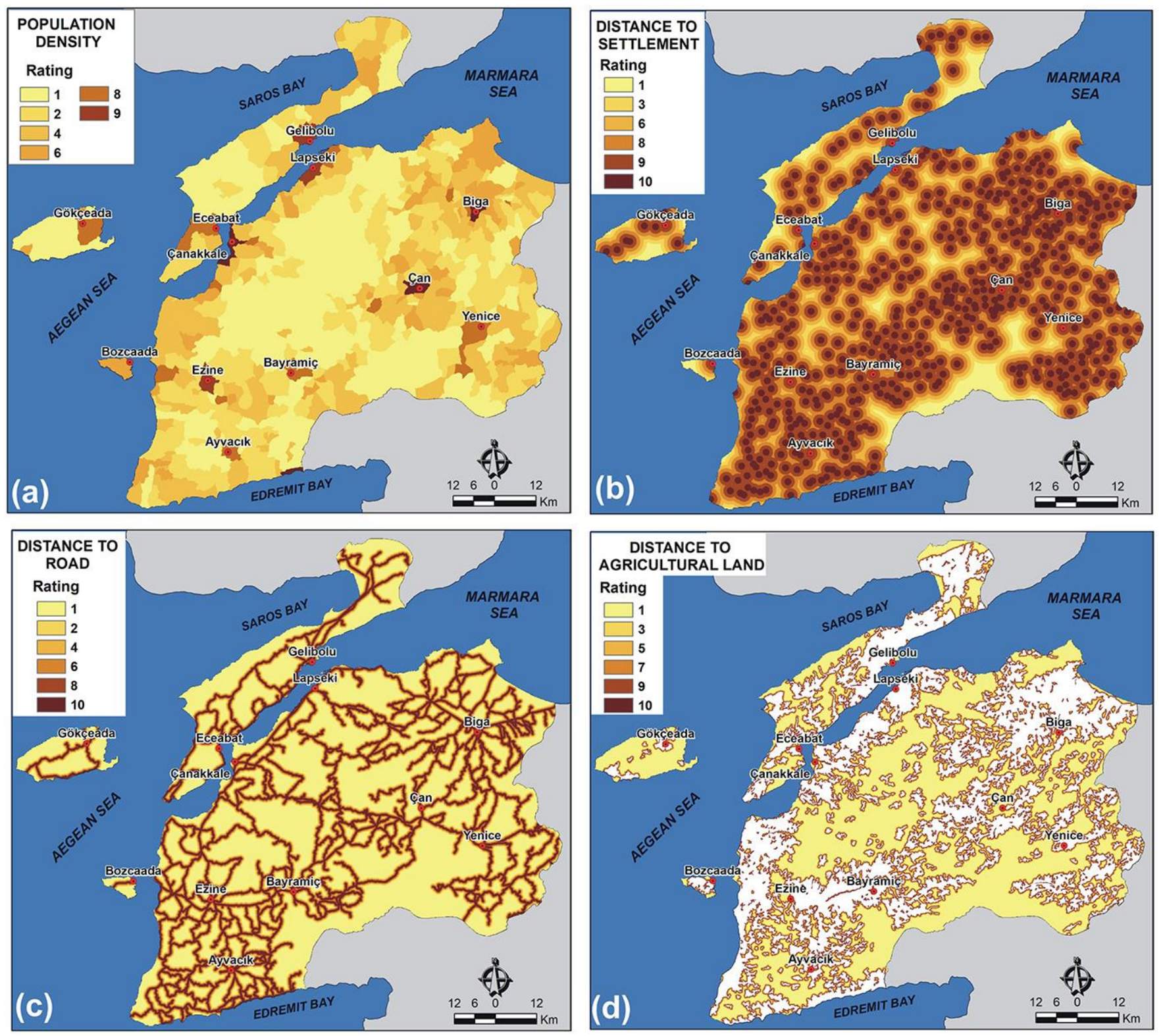

Figure 4. Ratings Assigned to the Human Factors for Forest Fire Risk: Population Density (a), Distance to Settlement (b), Distance to Road (c), and Distance to Agricultural Land (d).

\subsubsection{Weights of the Variables}

The impact levels, i.e. weights, of the considered variables in the forest fire risk analyses are not uniformly distributed. Therefore, it is important to determine the weight of each variable. This is a multilateral decision-making process. The weight of each variable in the study was calculated with AHP (Saaty, 1980), a Multi-Criteria Decision-Making (MCDM) technique relies on the formation of a hierarchy for the analysis of complicated multi-criteria problems. This technique determines the relative within-class superiority of elements for different layers in a view of the hierarchical structure and yields an effective solution for MCDM processes. According to Saaty (1980) a pairwise comparison matrix is created to determine the degree of significance of the criteria and sub-criteria by AHP. Decision-maker performs a value- and definition-based scoring in a way to determine the relative significances of the elements at a level and creates a pairwise comparisons matrix. As a result of the eigenvalue-eigenvector calculation this matrix, criterion weights with a total value of 1 (normalized weight coefficients) are retrieved. By a statistical test known as 
Akbulak, C., Tatli, H., Aygün, G., \& Sağlam, B. (2018). Forest fire risk analysis via integration of GIS, RS and AHP: The Case of Çanakkale, Turkey, Turkey, Journal of Human Sciences, 15(4), 2127-2143. doi:10.14687/jhs.v15i4.5491

Consistency Ratio, the consistency of the decisions made in the pairwise comparisons in AHP technique is calculated.

12 variables were used to determine forest fire risks in the research area. It is recommended that the number of variables should not exceed nine to calculate the weights by AHP method (Saaty 1980). Therefore, 12 variables were classified into sub-groups, so that the scores of main and sub-variables were separately calculated. The general weights of the sub-variables were obtained by multiplying weight scores of sub-variables by those of primary variables (Table 3). The obtained values were used to merge the values by weighted overlay method in GIS.

Table 3. Weights of Main Variables and Sub Variables

\begin{tabular}{|c|c|c|c|c|}
\hline Main variable & $\begin{array}{c}\text { Weight of main } \\
\text { variable }\end{array}$ & Sub variable & $\begin{array}{c}\text { Weight of sub } \\
\text { variable }\end{array}$ & $\begin{array}{c}\text { Global weight of sub } \\
\text { variable }\end{array}$ \\
\hline FWI & 0.117 & -- & -- & 0.117 \\
\hline Previous fires & 0.064 & -- & -- & 0.064 \\
\hline \multirow[t]{3}{*}{ Topography } & \multirow[t]{3}{*}{0.169} & Elevation & 0.493 & 0.083 \\
\hline & & Slope & 0.196 & 0.033 \\
\hline & & Aspect & 0.311 & 0.053 \\
\hline \multirow[t]{3}{*}{ Vegetation } & \multirow[t]{3}{*}{0.291} & Vegetation type & 0.540 & 0.157 \\
\hline & & Stand crown closure & 0.297 & 0.086 \\
\hline & & NDVI & 0.163 & 0.047 \\
\hline \multirow[t]{4}{*}{ Human factors } & \multirow[t]{4}{*}{0.360} & $\begin{array}{ll}\text { Distance } & \text { to } \\
\text { agricultural land }\end{array}$ & 0.120 & 0.043 \\
\hline & & Distance to settlement & 0.365 & 0.131 \\
\hline & & Distance to road & 0.235 & 0.085 \\
\hline & & Population density & 0.281 & 0.101 \\
\hline
\end{tabular}

\subsubsection{Risk Map}

The database produced on GIS and the variables considered in the analysis with the help of the applied model were simultaneously evaluated. Firstly, the raster layers corresponding to the variables of the risk analysis were merged by the weighted overlay method in GIS, and the risk score $\left(S_{j}\right)$ of $j$-th pixel is calculated with the following equation.

$$
S_{j}=\sum_{i=1}^{n} w_{i} x_{i}
$$

where $w_{i}$ represents weight of the corresponding variable $x_{i}$, and $n$ is the total number of the related variables, respectively. The $S_{j}$ value is calculated by using the weights of the variables given in Table 3 (the meaning of the abbreviations of the variables are seen in this table) as in the following.

$$
\begin{aligned}
& S_{j}=0.117 F W I+0.064 P F+0.083 E L V+0.033 S L+0.053 A S P+0.157 V G T+ \\
& 0.086 S C C+0.047 N D V I+0.043 D A L+0.131 D S+0.085 D R+0.101 P D
\end{aligned}
$$

In addition, the related $S_{j}$ is rescaled as in the following.

$$
I_{j}=\frac{\left|S_{\max }\right|}{5}
$$

The rescaled value $\left(I_{j}\right)$ ranges from 1 to 5 . In this expression, $S_{\max }$ and $I_{j}$ refer to the highest value and risk-class, respectively. The map of risk-classes was produced according to those standard riskvalues obtained by Equation (4). 
Akbulak, C., Tatli, H., Aygün, G., \& Sağlam, B. (2018). Forest fire risk analysis via integration of GIS, RS and AHP: The Case of Çanakkale, Turkey, Turkey, Journal of Human Sciences, 15(4), 2127-2143. doi:10.14687/jhs.v15i4.5491

\section{Results and Discussion}

The results of the weighted overlay method conducted based on the evaluation of 12 different variables revealed that areas at extreme, very high, high, and moderate risk account for $3.87 \%$, $63.46 \%, 32.13 \%$, and $0.53 \%$ (Table 4). No area in the province was observed to be listed as "no risk" or "low risk" area.

Table 4. The Rate of Forest Fires Risk in Çanakkale.

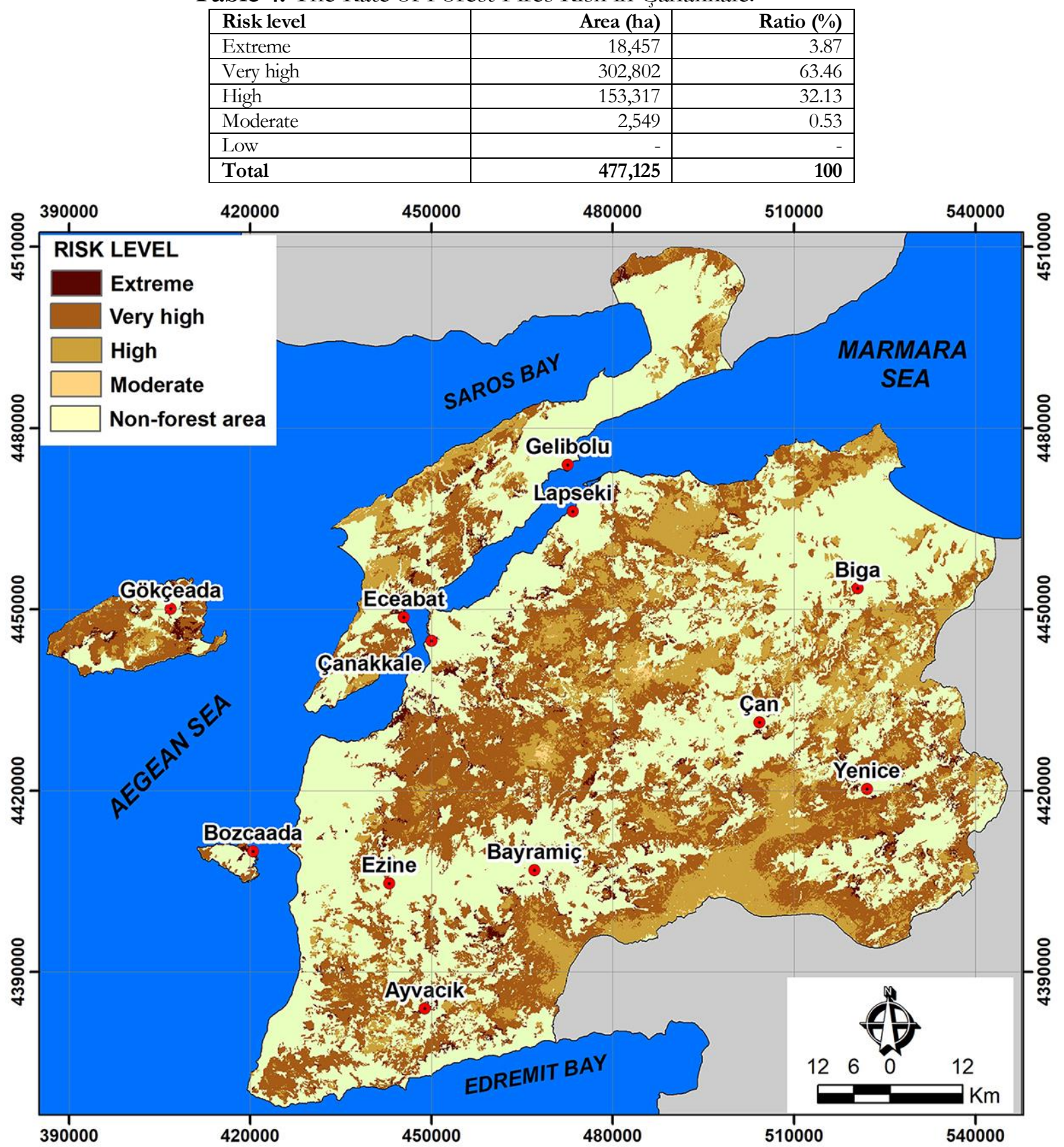

Figure 5. Forest Fire Risk Zone Map of the Study Area

Figure 5 indicates the forests across the province are at a high risk of forest fire. The forest fires with very high risk were observed in Ezine and Bayramiç towns of Çanakkale. Furthermore, the western sectors of Kaz Mountains, the periphery of Ayvacık town, and Gökçeada were found to be under the very high risk of fire. These areas prevalently covered with such fire-prone Calabrian pine, black pine, and bushes and hosting settlements and dense route networks were observed to 
Akbulak, C., Tatli, H., Aygün, G., \& Sağlam, B. (2018). Forest fire risk analysis via integration of GIS, RS and AHP: The Case of Çanakkale, Turkey, Turkey, Journal of Human Sciences, 15(4), 2127-2143. doi:10.14687/jhs.v15i4.5491

neighbor agricultural areas. Even though areas with extreme risk are rare, they are located where the conditions are extreme. The forests with the extreme risk are observed in the southeastern part of Gökçeada, northwestern part of Bozcaada, northwestern foot of Kaz Mountains, and the certain sections of the Gallipoli Peninsula. At-extreme-risk forests area are located at higher elevations of the Ida Mountains in the southeast of the province and Lapseki, Biga, and Çan. In these areas dominated by such plant species as firs, cedars, chestnuts, and beeches, elevation is relatively higher. Since the roads are sparsely distributed and less human activities in the Mount Ida, the fire risk is relatively lower than in the other parts of the province.

The analysis of the vegetation of the research area show that a large portion of the province $(68.2 \%)$ is covered by such dry plant types as Calabrian pine, black pine, scrub, Cyprus oak and kermes oak. Thus, it can be concluded that a great majority of the vegetation in Çanakkale consists of species highly prone to forest fire. The analysis of the distribution of these species by risk class showed that $5.5 \%, 77.7 \%, 16.8 \%$, and $0.063 \%$ are located in areas at extreme, very high, high, and moderate risk of fire, respectively. This evidences that nearly $83.5 \%$ of the areas dominantly covered by these species are at a very high or extreme risk. In addition, the comparison between the analysis results and the distribution of vegetation types manifested that $99 \%$ and $85 \%$ of these areas at extreme and very high risk, respectively, are covered by the fire-prone species. The low-risk plant species, such as walnut, cypress, abies, plane, chestnut, beech, cedar, and hornbeam were typologically analyzed too. The analyses denote that $11 \%$ of forest at very high risk and $0.1 \%$ of forests at extreme risk are covered by these plant species.

Another variable increasing the risk of fire is the meteorological factors in the study area. The FWI calculations in this study yielded no low-risk forest area in Çanakkale province. According to the FWI values, the areas at high and very high risk were found to account for $96.9 \%$. The results of the analyses indicate that $99.6 \%$ of the areas at extreme risk, $97.7 \%$ at very high risk, and $90.3 \%$ at high risk are located in areas at high and very high risk as reported in FWI. Thus, it can be suggested that parallels can be drawn between FWI and the analyses results in terms of risk classes.

It is known that forest fire risk is high in the densely populated areas. In these areas, the probability of fire outbreak due to the human activities, negligence, and the accident is higher than in the less populated areas. The fact that there are 602 settlements in the province and these settlements are connected to each other via a sophisticated dense road network tends to increase the risk. The comparison between the analyses results and distances to settlements showed that $97.8 \%$ of the extreme-risk areas are located in the $3-\mathrm{km}$ distance to a settlement. This rate is $80.1 \%$ for areas with very high risk, $48.1 \%$ for high-risk areas, and $0.4 \%$ for moderate-risk areas. These results reveal a positive relationship between the distance to settlements and fire risk.

According to the comparisons conducted to expose the relationship between the distance to roads and risk classes obtained in the present study, $91.4 \%$ of the areas at extreme risk are found in at most $1000 \mathrm{~m}$ away from the roads. It is $43.7 \%, 18.5 \%$, and $1.8 \%$ for the areas at very high, high, and moderate risk, respectively. Hence, it can be inferred that the risk gets higher as the distance to road gets shorter, but it will be lower if the distance is long.

The forests neighboring agricultural areas are at a higher risk. Especially the careless practices in the dry-agriculture areas and the stubble burning are among the fire-starting causes. In the present study, the effects of agricultural practices on fires were considered based on the forest distance to agricultural land. The fact that agricultural areas cover vast areas and they are interwoven into each other tends to increase forest fire risk.

The high number of fires in a certain area is significant to hint that it may be at a greater risk of fire. In Çanakkale province, 272 forest fires broke out between 2007 and 2016. According to the results of the buffer analyses conducted based on the starting points of the fires to include them into the evaluation, previous fires were found to be scattered across the province and to serve as a risk- 
Akbulak, C., Tatli, H., Aygün, G., \& Sağlam, B. (2018). Forest fire risk analysis via integration of GIS, RS and AHP: The Case of Çanakkale, Turkey, Turkey, Journal of Human Sciences, 15(4), 2127-2143. doi:10.14687/jhs.v15i4.5491

increasing factor. Besides, the comparison of at-risk areas with fire-hit sites is extremely important for the reliability of results obtained in the analyses. In this respect, the obtained risk zones were compared with the previous fire sites and starting points of the previous fires were observed to cluster in the areas at high and very high risk. Moreover, starting points were also revealed to neighbor settlements, agricultural areas, and roads.

The comparison between the results of the analyses and alike studies yields similar results concerning fire risk. For example, Karabulut et al. (2013) have determined a high risk of fire in Başkonuş Mountains in Kahramanmaraş and discovered that higher fire risk is imminent especially in dry forest areas, on south-facing slopes, and in the vicinity of roads and settlements. According to the study by Erten et al. (2005), it is reported that the forests at high risk and very high risk on the Gallipoli Peninsula account for the highest percentage. Therefore, the present study has similarities with these two studies in that risk zones are high in number. In addition, this study, unlike these abovementioned studies, reports that the areas at high and very high risk have greater percentages in reality.

In the current fire risk analyses, the weighted overlay method in GIS is frequently used (Jaiswal et al., 2002; Ghobadi et al., 2012; Assaker et al., 2012; Malik et al., 2013). Because no standardization of weight values of variables has been achieved in the abovementioned studies, the weight values obtained in this study are not standard, either. Unlike other studies, the weights were calculated by the AHP method. By this method, the weight values of the all variables were assigned to be "1" based on pairwise comparison matrices. The variables' weight values as "1" allow to obtain standard values ranging between " 0 " and "10". This lends itself to easy classification of the standard values in view of risk levels.

\section{Conclusions}

The results obtained in this study were reported by Akbulak et al. (2017) based on the the Scientific and Technical Research Council of Turkey (TUBITAK) project. The forest fires are unavoidable phenomena for Turkey just like for the Mediterranean countries and result in the destruction of thousands of hectares of forest areas. It is very difficult to estimate forest fires beforehand, but potential damages of the forest fires can be minimized with the aid of fire information systems and fire risk maps. Even if forest fires cannot be prevented thoroughly, risk analyses and predetermination of high-risk areas facilitate fire-fighting organizations since they support the efforts to take protective and preventive measures and the decisions to be made to fight fires. In-depth identification of fire risk levels and efforts to map these risks can make substantial contributions to firefighting.

The widespread coverage of areas at high and very high fire risks in Çanakkale requires protective and preservative precautions to fight forest fires. As required by protective measures, the citizens should be educated as to how to prevent forest fires and decrease outbreaks thereof. Moreover, in these areas where the fire risk is high, roadsides should be cleaned to decrease the amount of fuel, regulations should be passed in relation to the use of recreational areas, local people should be informed about the rules they are expected to observe and what to do in the case of fire in order to mitigate the risk of fire.

The present study shows that the employment of GIS, RS, and AHP in forest fire risk analyses could provide significant results. The fact that forest fires break out in various geographical factors entails the simultaneous operationalization of a great number of datasets. Because GIS is capable of evaluating complicated datasets by the same scale, it is a very efficient tool of forest fire risk analyses.

Moreover, it will be contributory in that it has a validity allowing for its use in other fire-prone areas. In consideration of up-to-date data obtained in studies like the present one, which 
Akbulak, C., Tatli, H., Aygün, G., \& Sağlam, B. (2018). Forest fire risk analysis via integration of GIS, RS and AHP: The Case of Çanakkale, Turkey, Turkey, Journal of Human Sciences, 15(4), 2127-2143. doi:10.14687/jhs.v15i4.5491

convertible into rigid and desired formats, in decision-making processes intended to fight forest fires. Besides, the conduction of elaborate studies into forest fires and factors effective therein are of great importance for the success of forest fire management. In forest fire risk analyses conducted in view of numerous parameters, inclusion of each parameter into the analysis is likely to cause some practical problems. Therefore, the conduction of in-depth research on the relationship between forest fires and one or several of the factors affecting forest fires is believed to make great contributions to the implementation of more effective protective and preventive measures.

\section{Acknowledgement}

The authors wish to thank TUBITAK (The Scientific and Technical Research Council of TurkeyProject No: 116O011) for financial support.

\section{References}

Adab, H., Kanniah, K.D. \& Solaimani, K. (2013). Modeling Forest Fire Risk in the Northeast of Iran Using Remote Sensing and GIS Techniques. Nat Hazards 65 (3): 1723-1743.

Akbulak C., Tatli H., Aygün G., Çekmek M. \& Sağlam B. (2017). Forest Fire Risk Analysis in Çanakkale Using Remote Sensing, GIS and AHS Methods. Project No: 116O011. The Scientific and Technical Research Council of Turkey (TUBITAK).

Altan, G. \& Türkeş, M. (2011). Hydroclimatologic Characteristics of the Forest Fires Occurred at the Çanakkale District and Relationship with Climate Variations. Aegean Geogrph J, 20 (2) (in Turkish).

Assaker, A., Darwish, T., Faour, G. \& Noun, M. (2012). Use of Remote Sensing and GIS to Assess the Anthropogenic Impact on Forest Fires in Nahri Ibrahım Watersheed Lebanon. Lebanese Sci J 13: 1528.

Biasi, R., Colantoni, A., Ferrara, C., Ranalli, F., Salvati, L. (2015). In-Between Sprawl and Fires: Long-Term Forest Expansion and Settlement Dynamics at the Wildland-Urban İnterface in Rome, Italy. Int J Sustain Dev World Ecol 22 (6): 467-475.

Bilgili, E., Sağlam, B. \& Başkent, E.Z. (2001). Fire Management Fire Hazard Rates and GIS. Sci and Eng 4: 88-97.

Bonneau, L.R, Shields, K.S. \& Civco, D.L. (1999). Using Satellite Images to Classify and Analyze the Health of Hemlock Forests Infested by the Hemlock Woolly Adelgid. Biol Invasions 1: 255-267.

Camia, A., Amatulli, G. \&San Miguel- Ayanz J. (2008). Past and Future Trends of Forest Fire in Europe. Ispra: Institute for Environment and Sustainability (EUR Technical Report EUR 23427 EN- 2008), European Commission JRC.

Carvalho, A., Flannigan, M.D., Logan, K.A., Miranda, I. \& Borrego, C. (2008). Fire Activity in Portugal and Relationship to Weather and the Canadian Fire Weather Index System. Intl J Wildland Fire 17: 328-338.

Carvalho, A.C., Carvalho, A., Martins, H., Marques, C., Rocha, A., Borrego, C., Viegas, D.X. \& Miranda, A.I. (2011). Fire Weather Risk Assessment under Climate Change Using a Dynamical Downscaling Approach. Env Model Softw 26: 1123-1133.

Chandra, S. (2005). Application of Remote Sensing and GIS Technology in Forest Fire Risk Modelling and Management of Forest Fires: A Case Study in the Gargwal Himalayan Region. Oosterom, PV, Zlatanova, S; Fendel, EM (eds), Geo-information for disaster management, pp 1239-1254. New York, Springer-Verlag Berlin, Heidelberg.

Clarke, K.C. (1997). Getting Started with Geographic Information Systems. Prentuce Hall Inc. New Jersey.

Çekmek, M. (2018). Analysis of Wildland Forest Fires by Canadian Forest Fire Weather Index Method: Çanakkale Case, Çanakkale Onsekiz Mart Unıversıty, Institute of Social Sciences (Unpublished Master's Thesis), (in Turkish).

Deeming, J.E, Burgan, R.E. \& Cohen, J.D. (1977). The National Fire- danger Rating System 1978. U.S. Department of Agriculture, Forest Service. Intermountain Forest and Range Experiment Station, Ogde, UT.

Dimitrakopulos, A.M., Bemmerzouk, A.M. \& Mitsopoulos, I.D. (2011). Evaluation of the Canadian Fire Weather Index System in Eastern Mediterranean Environment. Meteo Appl 18:83-93. 
Akbulak, C., Tatli, H., Aygün, G., \& Sağlam, B. (2018). Forest fire risk analysis via integration of GIS, RS and AHP: The Case of Çanakkale, Turkey, Turkey, Journal of Human Sciences, 15(4), 2127-2143. doi:10.14687/jhs.v15i4.5491

Dogan, H.M., Celep, F. \& Karaer, F. (2009). Evaluation of NDVI in Plant Community Composition Mapping: A Case Study for Tersakan Valley of Amasya County in Turkey. Int J Remote Sens 30: 3769 3798.

Dong, X.U., Shao, G., Limin, D.A.I., Zhanqing, H.A.O., Tang, L. \&Wang H. (2005). Mapping Forest Fire Risk Zones with Spatial Data and Principal Component Analysis. Sci China Tech Sci 49:140-149.

Erten, E., Kurgun, V., \& Musaoglu, N. (2004). Forest Fire Risk Zone Mapping from Satellite Imagery and GIS: a Case Study. In XXth Congress of the International Society for Photogrammetry and Remote Sensing, Istanbul, Turkey (pp. 222-230).

Erten, E., Kurgu, V. \& Musaoğlu, N. (2005). Establishment of Forest Fire Information System Using Remote Sensing and Geographic Information Systems. Union of Chambers of Turkish Engineers and Architects (UCTEA) Chamber of Surveying Engineers 10 ${ }^{\text {th }}$ Turkish Sci Tech Conf on Map; Ankara; Turkey (In Turkish).

Ertuğrul, M. (2005). Forest Fire Situation in Turkey and the World. ZKÜ J Faculty Forestry in Bartnn, 7: 43-50 (In Turkish).

ESRI. (1999). Using Arcview GIS. Environmental System Research Institute. Inc, Redlands, CA.

Gabban, A., Ayanz, S.M.G. \& Viegas, D.X. (2006). On the Suitability of the Use of Normalized Difference Vegetation Index for Forest Fire Risk Assessment. Int J Remote Sens 27:5095-5102.

GDF: Fire Statistics of General Directorate of Forest. (2007). Ankara: General Directorate Forest. Retrieved on https://www.ogm.gov.tr /ekutuphane/Sayfalar/Istatistikler.aspx (in Turkish).

Ghobadi, J.G., Gholizadeh, B. \& Dashliburun M.O. (2012). Forest Fire Risk Zone Mapping from Geographic Information System in Northern Forests of Iran (Case Study, Golestan province). Int Agri Crop Sci 4 (12): 818-824.

Goldammer, J.G. \& Mutch, R.W. (2001). Global Forest Fire Assessment. FAO Forest Resources Assessment Programme, Working Paper 55, Rome, Italy.

Gouveia, C.M, Trigo, R.M, Beguería, S. \& Vicente-Serrano, S.M. (2017). Drought Impacts on Vegetation Activity in the Mediterranean Region: An Assessment Using Remote Sensing Data and Multi-Scale Drought Indicators. Global and Planetary Change, 151: 15-27.

Güngördü, M. (1999). Plant Geography of the Marmara Region. Istanbul University Press, Istanbul (In Turkish).

Güngöroğlu, C. (2017). Determination of Forest Fire Risk with Fuzzy Analytic Hierarchy Process and its Mapping with the Application of GIS: The Case of Turkey/Çakırlar. Human Ecol Risk Assess, 23:2, 388-406.

Haines, A.D (1988) A Lower Atmosphere Severity Index for Wildland Fires. Natl Weather Dig 13: 23-27.

Huete, A., Leeuwen, W.V. \& Justice, C. (1999). MODIS-Vegetation Index (MOD13) Algorithm Theoretical Basic Document, Arizona.

Jaiswal, K., Mukherjee, S., Mukherjee, K.D \& Saxena, R. (2002). Forest Fire Risk Zone Mapping from Satellite Imagery and GIS. Int J Appl Earth Obs Geoinfo 4: 1-10.

Karabulut, M., Karakoç, A., Gürbüz \& M., Kizılelma, Y. (2013). Determination of Forest Fire Risk Areas in Başkonuş Mountain (Kahramanmaraş) Using Geographical Information Systems. Int Soc Res J 6:171179 (In Turkish).

Keetch, J.J\& Byram, G. M. (1968). A Drought Index for Forest Fire Control. Res. Pap. SE-38. Department of Agriculture, Forest Service, South-eastern Forest Experiment Station, Asheville, NC: USA.

Lillesand, T.M. \& Kiefer, R.W. (1987). Remote Sensing and Image Interpretation. New York: John Wiley and Sons.

Longley, P.A., Goodchild, M.F., Maguire, D.J. \& Rhind, D.W. (2001). Geographic Information Systems and Science. Chichester: John Wiley and Sons.

Malik, T., Rabban, G. \& Farooq, M. (2013). Forest Fire Risk Zonation Using Remote Sensing and GIS Technology in Kansrao Forest Range of Rajaji National Park, Uttarakhand, India. Int J Adv Remote Sens GIS 2: 86-95.

Marble, D.H., Calkins, H.W. \& Peqet, D.J. (1984). Basic Readings in Geographic Information Systems. Williamsville, NY: Spad Systems Limited.

Myneni, R.B, Keeling, C.D, Tucker, C.J, Aarar, G. \& Neamani RR. (1997). Increased Plant Growth in the Northern High Latitudes from 1981 to 1991. Nature 698-702.

Özşahin, E. (2014). Forest Fire Susceptibility Analysis Using GIS and AHP: The Case of Antakya Forestry Operation Directorate Route. Educ Soc Sci J 1: 50-71.

Potter, B.E., Winkle, J.A., Dwight, F.W., Ryan, P.S. \& Xindi, B. (2008). Computing the Low-Elevation Variant of the Haines Index for Fire Weather Forecasts. Weather Forecast 23: 159-167. 
Akbulak, C., Tatli, H., Aygün, G., \& Sağlam, B. (2018). Forest fire risk analysis via integration of GIS, RS and AHP: The Case of Çanakkale, Turkey, Turkey, Journal of Human Sciences, 15(4), 2127-2143. doi:10.14687/jhs.v15i4.5491

Pradhan, B., Suliman, B.H.D.M. \& Awang, B.A.M. (2007). Forest Fire Susceptibility and Risk Mapping Using Remote Sensing and Geographical Information Systems (GIS). Disaster Manag 16: 344-352.

Saaty, T. (1980). The Analytic Hierarchy Process. McGraw Hill, New York.

Sağlam, B., Bilgili, E., Durmaz, D.B., Kadığullanı, İ.A. \& Küçük Ö. (2008). Spatio Temporal Analysis of Forest Fire Risk and Danger Using Landsat Imagery. Sensors 8: 3970-3987.

Sharma, D., Hoa, V., Cuong, V., Tuyen, T. \& Sharma N. (2009). Forest Fire Risk Zonation for Jammu District Forest Division Using Remote Sensing and GIS Using Remote Sensing and GIS. 7th Regional Conference, Hanoi, Vietnam.

Soto, M.E.C. (2012). The İdentification and Assessment of Areas at Risk of Forest Fire Using Fuzzy Methodology. Appl Geogr 35: 199-207.

Sowmya, S.V. \& Somashekar, R.K. (2010). Application of Remote Sensing and Geographical Information System in Mapping Forest Fire Risk Zone at Bahadra Santuary, India Imsear at Hellis. J Envir Bio 31: 969-974.

SPO (State Planning Organization). (2001). 8th Five-Year Development Plan, Forestry Specialization Report. Retrieved on www.kalkinma.gov.tr /Pages/ OzellhtisasKomisyonuRaporlari.aspx (In Turkish).

Sringeswara, N.A, Shivanna, B.M. \& Gowda, B. (2012). Forest Fire and Its Management in Kudremukh National Park. Western Ghats, India Using Remote Sensing and GIS. 13th Esri India User Conference, pp 1-9, New Delhi; India.

Tang, L., Shao, G.\& Dai, L. (2009). Roles of Digital Technology in China's Sustainable Forestry Development. Int J Sustain Dev World Ecol. 16 (2): 94-101.

Tatli H., Çekmek M., Akbulak C., Aygün G. \& Sağlam B. (2017a). Investigation of Çanakkale Forest Fires by Canadian Forest Fire Weather Index. International 8th Atmospheric Sciences Symposium - Atmos2017, İstanbul, Turkey, 1-4 November 2017, vol.1, pp.372-380.

Tatli H., Akbulak C., Aygün G., Çekmek M. \& Sağlam B. (2017b). Determining Risk of the Forest Fires In Canakkale Via Geographic Information Systems and Analytic Hierarchy Process. International 8th Atmospheric Sciences Symposium - Atmos2017, İstanbul, Turkey, 1-4 November 2017, vol.1, pp.381-392

Tatli, H. \& Türkeş, M. (2014). Climatological Evaluation of Haines Forest Fire Weather Index over the Mediterranean Basin. Meteo Appl21 (3):545-552.

Thakur, A.K. \& Singh, D. (2014). Forest Fire Risk Zonation Using Geospital Techniques and Analytic Hierarchy Process in Dehradun District, Uttarakhand, India. Univer J Envir Res Tech 4: 82-89.

Tonini, M., Pereira, M.G, Parente, J. \& Orozco, C.V. (2017). Evolution of Forest Fires in Portugal: from Spatio-Temporal Point Events to Smoothed Density Maps. Nat Hazards, 85(3), 1489-1510.

Turco, M., Llasat, C.M, Hardenberg, V.J \& Provenzale, A. (2014). Climate Change Impacts on Wildfires in a Mediterranean Environment. Clim Change 125: 369-380.

Turner, A. \& Lawson, B.D. (1978). Weather in the Canadian Forest Fire Danger Rating System. A User Guide to National Standards and Practices. (Information Report BC-X-177). Canadian Forest Service, Pacific Forest Research Centre, Victoria, BC.

Türkeş, M., \& Altan, G. (2012a). Meteorological and Hydro-Climatological Analysis of Large Forest Fires of Çanakkale in the Year of 2008. Aegean Geogrph J, 10(2):195-218 (in Turkish).

Türkeş, M., \& Altan, G. (2012b). Analysis of the Year 2008 Fires in the Forest Lands of the Muğla Regional Forest Service by Using Drought Indices. J Human Sci, 9(1), 912-931 (in Turkish).

USGS (USA Geological Survey). (2017). Landsat (L8 OLI/TIRS) Satellite Images, at Website. Retrieved on https://earthexplorer.usgs.gov/.

Van Wagner, C.E. (1987). Development and Structure of the Canadian Forest Fire Weather Index. (Forestry Technical Report 35, 37). Canadian Forestry Service, Ottowa.

Versini, P., Velasco, M., Cabello, A. \& Sempere-Torres, D. (2013). Hydrological Impact of forest Fires and Climate Change in Mediterranean Basin. Nat Hazards 66 (2): 609-628.

Viegas, D., Bovio, G., Ferreira, A., Nosenzo, A. \& Sol, B. (1999). Comparative Study of Various Methods of Fire Danger Evaluation in Southern Europe. Int J Wildland Fire 9: 235-246.

Vilar, L., Nieto, H. \& Martin M.P. (2010). Integration of Lightning- and Human-Caused Wildfire Occurrence Models. Human Ecol Risk Assess 16 (2): 340-364.

Yin, H., Kong, F. \& Li, X. (2004). RS and GIS-Based Forest Fire Risk Zone Mapping in Da Hinggan Mountains. Chinese Geogr Sci 14: 251-257.

Zheng, S., Li, C., Su, X., Quanyi, Q. \& Shao G. (2011). Risk Assessment for Effective Prevention and Management of Forest Fires in Lijiang City. Int J f Sustain Dev World Ecol 18 (6): 509-514. 